\title{
Pencegahan Lesi Aterosklerosis Oleh Asam Alfa Lipoat Pada Aorta Mencit Jantan (Mus Musculus) Yang Diberi Diet Tinggi Kolesterol
}

\author{
Ismawati $^{1}$, Winarto ${ }^{2}$, Rezki Permata Sari ${ }^{3}$
}

\begin{abstract}
Atherosclerosis can happen easily on animal that are given high cholesterol diet. Alpha lipoic acid is universal antioxidant that very effective to reduce free radicals, include lipid peroxide. The goal of this research was to find out the prohibition of atherosclerosis lesion development on male mice aorta that was given high cholesterol diet by alpha lipoic acid. This was an experimental laboratory research with post test only design. Eighteen adult male mice were segregated into three groups labelled as group $\mathrm{NaCl} 0,9 \%$, yolks and ALA.. The experiment was design for 6 weeks. The measured parameter was atherosclerosis lesion score of groups labelled. The statistical test result showed the significant difference of some tested groups. There was a statistically significant difference between alpha lipoic acid and yolks group ( $\mathrm{p}=0,008)$, but there is no significant difference was found between ALA and $\mathrm{NaCl} 0,9 \%$ group $(\mathrm{p}=0,126)$. As the conclusion, this study proves that alpha lipoic acid has the effects to prohibition of atherosclerosis lesion development on male mice aorta that are given high cholesterol diet.
\end{abstract}

Keywords: atherosklerosis, hypercholesterolemia, alpha lipoic acid

Perubahan pola hidup masyarakat dan pola makan telah memicu timbulnya berbagai gangguan kesehatan seperti diabetes melitus dan penyakit kardiovaskular (PKV). ${ }^{1}$ Studi epidemiologi menunjukkan bahwa ada keterkaitan antara status kesehatan dan usia harapan hidup suatu masyarakat dengan pola konsumsi. Masyarakat yang mengonsumsi diet tinggi lemak mempunyai resiko lebih tinggi untuk menderita penyakit degeneratif, misalnya penyakit hati dan $\mathrm{PKV}{ }^{2}$

Aterosklerosis merupakan penyakit degeneratif arteri besar dan sedang, yang ditandai dengan penimbunan lipid dan fibrosis. Aorta dan arteri besar maupun sedang paling banyak terkena dan menyebabkan terjadinya keadaan klinis yang bermacam-macam. ${ }^{3}$

\footnotetext{
1 Coresponding Author. Bagian Biokimia Fakultas Kedokteran Universitas Riau. ${ }^{2}$ Bagian Patologi Klinik Fakultas Kedokteran Universitas Riau. ${ }^{3}$ Fakultas Kedokteran Universitas Riau, J1.Diponegoro No.1 Pekanbaru
}

Aterosklerosis di Amerika serikat merupakan penyebab kematian paling utama dibandingkan dengan penyakit lain, sehingga memicu banyak penelitian yang mana menghasilkan perbedaan pendapat tentang cara pengendaliannya. ${ }^{4}$ Penyakit kardiovaskular yang di dalamnya termasuk penyakit jantung koroner (PJK) menempati urutan pertama penyebab seluruh kematian didunia. Berdasarkan survei kesehatan rumah tangga (SKRT) tahun 2001, penyebab kematian nomor satu di Indonesia adalah PKV dengan prevalensi 26,4\%. Data terakhir Dinas Kesehatan menyebutkan, hingga tahun 2010 prevalensi PKV di Indonesia terus meningkat dan akan tetap menjadi penyebab kematian nomor satu, jika tidak dikendalikan secepatnya. ${ }^{5}$

Hasil penelitian The Cholesterol Lowering Atherogenesis Study (CLAS) menunjukkan pemberian antioksidan memberikan pengaruh yang signifikan terhadap penurunan penyakit aterosklerosis. ${ }^{1}$ Asam alfa lipoat (alpha lipoid acid = ALA) menunjukkan aktivitas antioksidan yaitu menangkap radikal bebas serta mempunyai 
kemampuan mendaur ulang antioksidan lain seperti vitamin $\mathrm{C}$, vitamin $\mathrm{E}$, glutation dan juga memiliki kemampuan mengatur kadar lipid darah yaitu melindungi low density lipoprotein (LDL) dari oksidasi dan melindungi dari resiko PKV. ${ }^{1,6}$

Biasanya pemakaian ALA sebagai suplemen antioksidan di Indonesia adalah untuk memelihara kesehatan kulit, untuk penderita diabetes melitus dan untuk memelihara fungsi hati. Penggunaan ALA sebagai suplemen dalam pencegahan aterosklerosis belum dikenal. $^{7}$

Penelitian yang dilakukan oleh Amom dkk melaporkan adanya penurunan kolesterol total plasma dan kadar LDL plasma, dan juga adanya pengurangan pembentukan lesi aterosklerosis pada aorta kelinci yang dibandingkan dengan aorta kelinci yang tidak diberi suplementasi ALA yang diukur menggunakan sistem analisis komputer. ${ }^{8}$

Penelitian yang dilakukan oleh Shih melaporkan penurunan kolesterol total sebesar $40 \%$ dan penurunan â-lipoprotein sebesar $42 \%$ pada burung puyuh. Shih menyimpulkan bahwa ALA mempunyai efek proteksi dalam mencegah peningkatan lipid darah dan aterosklerosis. ${ }^{6}$ Walaupun menurut Shih, aterosklerosis pada aorta dari burung puyuh dianggap karakteristik dari penyakit manusia, namun dalam penerapan hasil ekstrapolasi pada manusia, harus didukung dengan penelitian pada hewan lain. ${ }^{6}$

Tujuan penelitian ini adalah untuk mengetahui kemampuan ALA untuk mencegah pembentukan lesi aterosklerosis pada aorta mencit yang diberi diet tinggi kolesterol.

\section{METODE}

Penelitian ini merupakan penelitian eksperimental dengan design post test only with control.

\section{Alat dan Bahan Penelitian}

Alat yang digunakan dalam penelitian ini adalah spuit $1 \mathrm{cc}$, sonde lambung, minor set, tissue cassette, tissue processor (micro-spin STP-120), dan embedding center (microm EC 350-1), manual microtom (microm HM 315), waterbath (microm SB
80), oven (memmert), kaca objek, deck glass, mikroskop cahaya (motic Bl series system microscopes).

Bahan yang digunakan dalam penelitian adalah kuning telur mentah yang berasal dari jenis ayam ras sebagai diet tinggi kolesterol, asam alfa lipot sebagai anti oksidan, aquadest sebagai pengencer, $\mathrm{NaCl}$ 0,9\% sebagai kontrol negatif, jagung lumat merek B12 sebagai pakan mencit, eter, formalin $10 \%$, xylol I, II, III, parafin cair, etanol, lithium karbonat, alkohol 70\%, 80\%, 96\%, hematoxylin eosin, dan entelan.

\section{Prosedur Penelitian}

Mencit diadaptasikan dengan lingkungan baru selama satu minggu. Mencit diberi makan dan minum seperti biasa. Mencit dibagi dalam 3 kelompok, masing-masing kelompok terdiri dari 6 mencit. Masing-masing kelompok akan memperoleh perlakuan yang berbeda.

- Kelompok I yaitu kelompok mencit yang diberi larutan $\mathrm{NaCl}$ 0,9\% melalui sonde lambung disamping diet standar sebagai kontrol negatif.

- Kelompok II yaitu kelompok mencit yang diberi kuning telur 20,5 g/kgBB melalui sonde lambung disamping diet standar

- Kelompok III yaitu kelompok mencit yang diberi diet kuning telur 20,5 g/kgBB melalui sonde lambung dan ALA 0,078 g/kgBB disamping diet standar.

Asam lipoat diberikan selama 2 minggu pada kelompok III yaitu pada minggu ke-5 dan 6 perlakuan. Penentuan dosis asam alfa lipoat berdasarkan dosis aman asam alfa lipoat yang dikonsumsi oleh manusia, yaitu $200-1800 \mathrm{mg} /$ hari. $^{6}$ Di dalam penelitian ini dipakai dosis $600 \mathrm{mg} /$ hari. Penentuan dosis berdasar atas dosis terapi pada manusia (berat badan $70 \mathrm{~kg}$ ) dikonversikan kepada mencit (berat badan $20 \mathrm{~g}$ ).

Kuning telur diberikan pada kelompok II dan III selama 6 minggu. Kuning telur yang diberikan adalah kuning telur ayam mentah yang berasal dari jenis ayam ras dengan menggunakan sonde sehari sekali pada siang hari selama 6 minggu. Pemberian kuning telur maksimal $1 \mathrm{ml}$ pada mencit. Pada kelompok III pada minggu ke-5 dan 6 diberikan 
kuning telur dan ALA. Interval antara pemberian ALA dengan pemberian pakan tinggi kolesterol adalah selama 1 jam.

Pengambilan aorta dilakukan setelah mencit dikorbankan terlebih dahulu. Aorta yang baru diambil di tempatkan dalam wadah yang telah beri label untuk masing-masing kelompok, kemudian ditambahkan formalin 10\% sampai seluruh terendam dan segera ditutup rapat. Setelah itu sampel aorta dibawa ke Laboratorium Patologi Anatomi Rumah Sakit Umum Daerah Arifin Achmad Pekanbaru untuk dibuat slide mikroskopik. Pewarnaan yang digunakan adalah hematoxylin eosin (HE). Analisis dilakukan dibawah mikroskop cahaya. Penilaian dilakukan dengan pembesaran 400x. Setiap parameter dinilai dengan skoring. Skor tiap slide mikroskopik dijumlahkan dan dihitung rata-ratanya. Skor aorta pada masing-masing kelompok dibandingkan.

Tabel 1. Parameter penilaian lesi aterosklerosis ${ }^{9}$

\begin{tabular}{ll}
\hline PARAMETER & SKOR \\
\hline Utuh & 0 \\
terdapat makro fag, sel busa & 1 \\
terdapat akumul asi lipid intrasel otot polos & 2 \\
grade 2 + sedikit lipid ekstrasel otot polos & 3 \\
grade 2 + banyak lipid ekstrasel otot polos & 4 \\
inti lipid dan lapisan fibrosis & 5 \\
defek permukaan, hematom, trombus & 6 \\
\hline
\end{tabular}

\section{HASIL}

\section{Gambaran histopatologi aorta mencit} seluruh kelompok perlakuan Gambaran histopatologi aorta mencit kelompok I

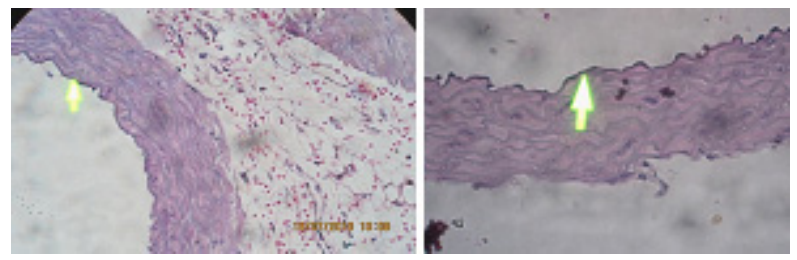

Gambar 1. Gambaran mikroskopik aorta mencit kelompok $\mathrm{NaCl} 0,9 \%$

Gambar 1 memperlihatkan gambaran mikroskopik aorta mencit pada kelompok percobaan yang diberi $\mathrm{NaCl} 0,9 \%$. Pada gambar terlihat pembuluh darah aorta dengan tampilan yang utuh, tidak ditemukan adanya butiran sel radang, sel busa, lipid intrasel, lipid ektrasel, lapisan fibrosis maupun trombus.

\section{Gambaran histopatologi aorta mencit kelompok II}
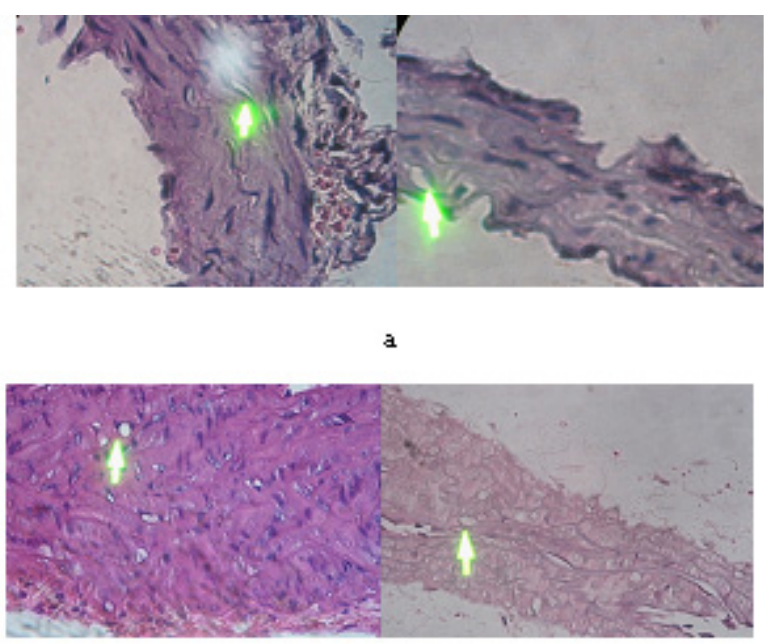

$\mathrm{b}$

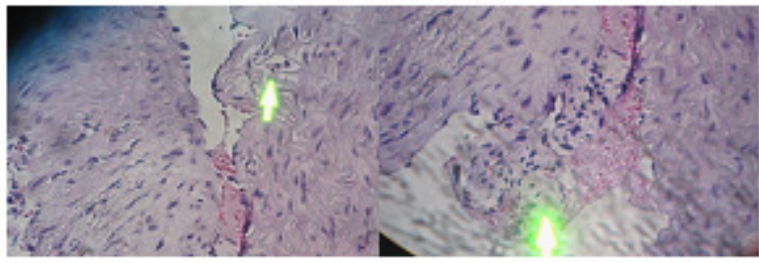

Gambar 2. Gambaran mikroskopik aorta mencit kelompok kuning telur 
(a) gambaran lesi aterosklerosis pada aorta mencit dengan skor 3

(b) gambaran lesi aterosklerosis pada aorta mencit dengan skor 4

(c) gambaran lesi aterosklerosis pada aorta mencit dengan skor 6

Pada gambar 2 di atas terlihat adanya pembentukan lesi aterosklerosis pada aorta mencit yang diberi kuning telur, dimana pada gambar 2(a) ditemukan adanya lipid ektrasel yang jumlahnya sedikit pada penampang dinding aorta, begitu juga dengan gambar 2(b) juga ditemukan adanya lipid ektrasel dalam jumlah yang relatif banyak jika dibandingkan dengan gambar 2a, lain halnya dengan gambar 2(c) dimana ditemukan sudah terbentuknya trombus dalam lumen aorta.

\section{Gambaran histopatologi aorta mencit kelompok ALA}

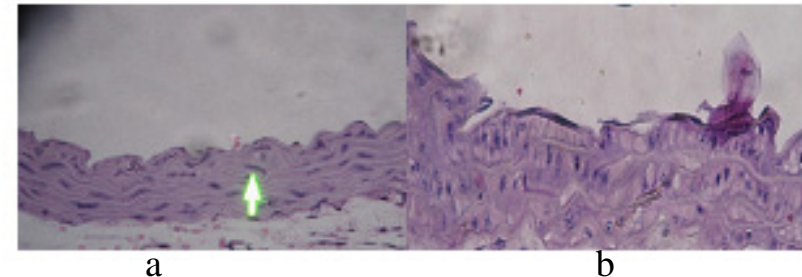

Gambar 3. Gambaran mikroskopik aorta mencit kelompok ALA (a) gambaran lesi aterosklerosis pada aorta mencit dengan skor 0

(b) gambaran lesi aterosklerosis pada aorta mencit dengan skor 1

Pada gambar di atas terlihat pada sebagian sediaan aorta tidak mengalami pembentukan lesi dan masih ada sebagiannya lagi yang mengalami pembentukan lesi aterosklerosis pada aorta mencit yang diberi ALA, namun sudah mengalami penurunan jika dibandingkan dengan kelompok yang hanya diberi kuning telur saja. Pada gambar 3(a) tidak ditemukan adanya butiran sel radang, sel busa, lipid intrasel, lipid ektrasel, lapisan fibrosis maupun trombus, yang artinya pembuluh darah aorta dengan tampilan utuh, sedangkan pada gambar 3(b) sudah ditemukan sel radang dan sel busa pada sediaan aorta mencit.

Total skor lesi aterosklerosis aorta mencit, dari yang terbesar sampai yang terkecil secara berturutturut adalah kelompok kuning telur, kelompok asam alfa lipoat dan kelompok $\mathrm{NaCl} \mathrm{0,9 \%}$ (tabel 2).

Tabel 2. Skor rata-rata gambaran histopatologi mencit jantan pada berbagai perlakuan

\begin{tabular}{llll}
\hline & & Kelomp ok & \\
Ulangan & I & II & III \\
\hline 1 & 0 & 4 & 1 \\
2 & 0 & 3 & 1 \\
3 & 0 & 3 & - \\
4 & 0 & 6 & 0 \\
5 & 0 & 4 & 1 \\
6 & 0 & - & 0 \\
\hline
\end{tabular}

Untuk mengetahui signifikansi perbedaan tersebut dilakukan analisis uji Kruskal-Wallis dan untuk mengetahui kelompok yang memberikan perbedaan bermakna tersebut dilakukan analisis post hoc dimana untuk uji Kruskal-Wallis digunakan uji Mann-Whitney. Hasilnya dapat dilihat pada Tabel 4.2 berikut ini; 
Tabel 3. Perbandingan pengaruh asam alfa lipoat terhadap skor lesi aterosklerosis aorta mencit dengan Mann-Whitney $(\mathrm{p}<0,05)$

\begin{tabular}{ll}
\hline Perlakuan & Signifikansi \\
\hline NaC1 $0,9 \%$ vs Kuning telur & $(\mathrm{p}=0,004)^{*}$ \\
Kuning telur vs A sam alfa lipoat & $(\mathrm{p}=0,008)^{*}$ \\
NaC1 $0,9 \%$ vs Asam alfa lip oat & $(\mathrm{p}=0,126)^{* *}$ \\
\hline
\end{tabular}

\section{Keterangan:}

* (significant): terdapat perbedaan yang bermakna secara statistik

** ns (non significant): tidak ada perbedaan yang bermakna secara statistik

Pada Tabel 3 dapat dilihat bahwa terdapat perbedaan yang bermakna antara kelompok I dengan kelompok II, dan kelompok II juga memiliki perbedaan yang bermakna secara statistik dengan kelompok III, namun kelompok I dengan kelompok III tidak terdapat perbedaan yang bermakna bermakna secara statistik.

\section{PEMBAHASAN}

Kuning telur sering diberikan pada hewan coba dengan tujuan meningkatkan kadar kolesterol. Tingginya kenaikan kadar kolesterol karena kuning telur yang diberikan mengandung tinggi kolesterol dan asam lemak jenuh. ${ }^{10}$ Aterosklerosis dapat timbul dengan mudah pada hewan yang diberi diet tinggi kolesterol. Oleh karena itu, komponen utama plak aterosklerosis adalah kolesterol. ${ }^{11}$

Kelompok yang diberi perlakuan diet tinggi kolesterol pada penelitian ini memperlihatkan gambaran lesi aterosklerosis pada sediaan mikroskopis berupa sel busa, lipid ekstrasel, dan trombus pada sediaan aorta mencit. Kolesterol diangkut didalam lipoprotein pada plasma, proporsi terbesar terdapat di dalam LDL. Diet tinggi kolesterol meningkatkan pembentukan LDL plasma dimana LDL memiliki sifat aterogenik sehingga melekat kuat pada dinding pembuluh darah dan menyebabkan penimbunan komponen lipid. Keadaan ini mempermudah terjadinya proses oksidasi oleh radikal bebas dan menyebabkan kerusakan oksidatif pada lipid yang dikenal dengan peroksidasi lipid. ${ }^{12}$

Menurut hipotesis modifikasi oksidatif, LDL awalnya terakumulasi di lapisan subendotel arteri dan teroksidasi oleh senyawa-senyawa oksidan, antara lain ion superoksida yang disekresi oleh makrofag dan sel-sel otot polos menjadi minimally modified LDL. ${ }^{13,14}$ Minimally modified LDL belum bersifat sitotoksik terhadap sel endotel, tetapi memicu gen-gen tertentu seperti gen untuk cell adhesion molecule (CAM), gen-gen kemokin, serta gen-gen faktor pertumbuhan (platelet derivated growth factor (PDGF), fibroblast growth factor (FGF) dan monocyte stimulating factor (M-SCF). Ekspresi gen-gen sel endotelium tersebut memperparah keadaan. Peningkatan pemaparan CAM menyebabkan lebih banyak monosit menempel pada endotelium. Setelah menempel, selsel tersebut akhirnya menembus lapisan endotelium memasuki jaringan subintima yang dibantu oleh senyawa-senyawa kemokin, sedangkan M-SCF memicu diferensiasi monosit menjadi makrofag. Akibatnya lebih banyak makrofag dalam ruang subintima sehingga pembentukan sel busa semakin banyak. Selanjutnya PDGF akan memicu migrasi sel otot polos memasuki ruang subintima, sedangkan FGF memicu proliferasi sel otot polos, fibroblas dan juga memicu sekresi kolagen oleh fibroblas. Selanjutnya terjadi perangsangan oksidasi LDL lebih lanjut. Oksidasi LDL bersifat sitotoksik sehingga pada akhirnya menyebabkan nekrosis sel busa dan terjadilah penumpukan lipid ekstrasel. Nekrosis endotelium karena pengaruh oksidasi LDL memicu terjadinya trombus. ${ }^{15}$

Berdasarkan hasil penelitian terbukti bahwa pemberian asam alfa lipoat selama 2 minggu dapat menurunkan skor lesi aterosklerosis pada aorta mencit jika dibandingkan dengan kelompok yang diberi perlakuan diet tinggi kolesterol. Hasil penelitian yang didapat sesuai dengan hasil penelitian sebelumnya. Amom (2008) ${ }^{8}$ selama 10 minggu pada kelinci yang diberi diet tinggi kolesterol 1\% dan menggunakan ALA 4,2 g/kgBB perhari sebagai antioksidan, dimana ALA diberikan 
melalui oral. Penelitian ini melaporkan adanya penurunan kolesterol total plasma dan kadar LDL plasma, dan juga adanya pengurangan pembentukan lesi aterosklerosis pada aorta kelinci yang dibandingkan dengan aorta kelinci yang tidak diberi suplementasi ALA yang diukur menggunakan sistem analisa komputer. ${ }^{8}$

Asam alfa lipoat dan bentuk tereduksinya, DHLA adalah antioksidan yang kuat. ALA dapat meningkatkan glutation jaringan dan meregenerasi level vitamin C dan E endogen. Hal-hal ini sepanjang demonstrasinya dikualifikasikan sebagai kandidat utama untuk mengevaluasi peningkatkan kemampuan dalam mencegah disfungsi endotel. ${ }^{6,14}$ Asam alfa lipoat larut dalam lemak dan air. Asam alfa lipoat sangat efektif untuk mereduksi radikal bebas, termasuk lipid peroksida, pada membran selular karena ALA larut lemak. Asam alfa lipoat juga mampu untuk mendapatkan akses ke sitosol, di mana secara efektif menangkap radikal bebas pada mitokondria karena ALA larut air. ${ }^{16}$

Stres oksidatif merupakan salah satu faktor yang menghubungkan antara hiperkolesterolemia dengan patogenesis aterosklerosis. ${ }^{8}$ Efek anti inflamasi dan antiaterosklerosis berhubungan dengan kemampuan ALA dalam menurunkan akumulasi makrofag pada dinding arteri melalui mekanisme penghambatan macrophag associated integrin (Mac-1) dan MCP-1. Asam alfa lipoat juga mensupresi ekspresi CAM sehingga mencegah selsel darah putih (granulosit, monosit dan limfosit) menempel pada dinding pembuluh darah. ${ }^{15,17}$

Adanya pengurangan pembentukan lesi aterosklerosis pada aorta mencit pada penelitian ini juga dapat dihubungkan dengan penurunan kadar kolesterol pada plasma mencit maupun penurunan kadar MDA pada plasma mencit. Asam alfa lipoat dapat menurunkan kadar kolesterol total darah melalui pengaturan aktivitas enzim yang berperan dalam metabolisme kolesterol. Asam alfa lipoat dapat menurunkan aktivitas HMG-CoA reduktase. Enzim HMG-CoA reduktase adalah enzim yang berperan dalam biosintesis kolesterol dengan cara mengubah HMG-CoA menjadi mevalonat dan akhirnya mevalonat akan diubah menjadi kolesterol. Adanya penurunan aktivitas HMG-Ko-A reduktase akan menyebabkan sintesis kolesterol dari hati akan menurun. ${ }^{18}$ Asam alfa lipoat juga mampu untuk menginisiasi sintesis reseptor LDL di hati sehingga meningkatkan uptake kolesterol kembali ke sistem hepatik. $^{8}$

\section{KESIMPULAN}

Asam alfa lipoat dapat menurunkan dapat mencegah pembentukan lesi aterosklerosis aorta mencit jantan yang diberi diet tinggi kolesterol. Hasil uji Mann-Whitney menunjukkan adanya hubungan yang bermakna antara kelompok asam alfa lipoat dengan kelompok kuning telur $(\mathrm{p}=0,008)$.

\section{UCAPAN TERIMA KASIH}

Penulis mengucapkan terima kasih kepada Fakultas Kedokteran Universitas Riau yang mendanai penelitian ini. Penulis juga mengucapkan terima kasih kepada semua pihak yang membantu dalam menyelesaikan penelitian ini.

\section{DAFTAR PUSTAKA}

1. Widowati W. Peran anti oksidan sebagai agen hipokolesterolemia, pencegah oksidasi lipid dan aterosklerosis.Majalah kedokteran Damianus.2007;6(3):5-9.

2. Thadeus MS, Marwoto W, Wuyung PE, Jusman SWA, Chairani N. Perubahan gambaran histopatologik hati, jantung dan aorta akibat pencekokan. Profesi medika. 2005;5(2):44-55.

3. Undewood JCE. Patologi umum dan sistematik. Vol 2. Jakarta: EGC; 2000. 326-332.

4. Robbins dan Kumar. Buku ajar patologi II. Jakarta: EGC; 1995. 1-11.

5. Departemen Kesehatan. Obesitas dan kurang aktivitas fisik menyumbang 30\% kanker. 2009. [diakses 1 Mei 2010]. Diunduh dari: http:// $\underline{\mathrm{w}} \mathrm{w} \cdot \mathrm{d}$ e $\mathrm{p} k \mathrm{k}$ e $\mathrm{s} \cdot \mathrm{g} \quad \mathrm{o} \cdot \mathrm{i} \mathrm{d} /$ index.php?option=news\&task=viewarticle \&sid=3328.

6. Wollin SD, Jones PJ. á- Lipoic acid and cardiovascular disease.. J.Nut. 2003;133:33273330 .

7. Composition, indication and usage of pharmacy in Indonesia. 2008. [diakses 21 Mei 2010]. Diunduh dari: http://www.wira.swatika.web.id/ 
composition-indication-and-usage-of-pharmacyin-indonesia.htm.

8. Amom Z, Zakaria Z, Mohamed J, Azlan A, Bahri $\mathrm{H}$, Baharuruldin MTH, et al. Lipid lowering effect of antioxidant alpha lipoic acid in experimental atherosclerosis. J Clin Biochem Nutr. 2008 sept ;43(2):88-94.

9. Joong SS, Sang YL, Ho-dirk K. Quantitative analysis of aortic atherosklerosis in korean female: Anecropsy study. J Korean Med Sci. 2007;22.536-45.

10.Bartov I, Reiser R, Henderson G. Hypercholesterolemic effect in the female rat of egg yolk versus crystalline cholesterol dissolved in lard. Journal of nutrition. 1973;103:1400-05.

11.Japardi, Iskandar DR. Aterogenesis dan infark aterotrombotik. Medan: USU digital library; 2002.

12.Agus ZAN. Stres oksidatif dan penyakit degeneratif. Jurnal Kedokteran Yarsi. 2002;10(3):69-73.
13.Corwin EJ. Buku saku patofisiologi. edisi 3 revisi. Jakarta: EGC; 2009. 477-484.

14.Diaz MN, Frei B, Vita JA, Keaney JF. Antioxidants and atherosclerotic heart disease. N Engl J Med. 1997;337:408-416.

15.Bast A, Cadenas E. Kapita selekta ilmu kedokteran molekuler. Jakarta: EGC; 2000.

16.Biewenga GP. The pharmacology of the antioxidant lipoic acid. Gen Pharmacol. 1997;29:315-331.

17.Zhang WJ, Bird KE, McMillen TS, LeBoeuf, Hagen TM, Frei B. Dietary alpha lipoic acid suplementation inhibids atherosclerosis lesion development in apolipoprotein E-deficient and apolipoprotein $\mathrm{E} / \mathrm{LDL}$ receptor-deficient mice. Circulation AHA Journal; 2008. 421-428.

18. Othman F, Budin SK, Louis SR, Bakar MA, Radzi M, Ozman K, et al. Effect of alpha lipoic acid on oxidative stress and vascular wall of diabetic rats. Romanian Journal of Morphology and Embryology 2009;50:23-30 